\title{
DAMPAK KAPITALISME GLOBAL TERHADAP PENDIDIKAN ISLAM
}

\author{
1 Emawati \\ ${ }_{1}^{1}$ FTK UIN Mataram \\ Email: emawati@uinmataram.ac.id
}

\begin{abstract}
Abstrak: Tujuan Kajian ini adalah untuk mengetahui bagaimana dampak kapitalisme global terhadap pendidikan islam. Penelitian ini termasuk dalam kategori penelitian kepustakaan (library research). Teknik pengumpulan data, dalam hal ini penulis akan melakukan identifikasi wacana dari buku-buku, makalah atau artikel, majalah, jurnal, web (internet), ataupun informasi lainnya yang berhubungan dengan judul penulisan untuk mencari hal-hal atau variabel yang berupa catatan, transkip, buku, surat kabar, majalah dan sebagainya. Teknik yang digunakan dalam tesis ini adalah analisis data model Miles dan Huberman.Aktifitas analisis data model ini antara lain, reduksi data (data reduction), display data dan gambaran konklusi atau verifikasi (conclusion drawing/verification). Hasil kajian menunjukkan bahwa humanisme religius sebagai paradigma, maka orientasi pendidikan Islam dari tingkat dasar sampai perguruan tinggi, formal, dan informal perlu diarahkan ke titik ini. Dengan paradigma ini, pendidikan Islam, khususnya konteks Indonesia (perifer), diharapkan mampu menyiapkan dirinya sebagai suatu sistem yang dapat diandalkan dalam menyiapkan peserta didik yang siap menghadapi segala dampak yang ditimbulkan akibat kapitalisme global yang dikuasai negara-negara Barat (center).Dengan paradigma ini, peserta didik dapat tumbuh kembang dengan segala potensi dirinya masing-masing, dengan tetap berpegang teguh pada nilai-nilai religius. Dengan demikian pendidikan Islam tidak akan mengabaikan pentingnya pendidikan jasmani dan rohani serta pendidikan alam, tidak mendikotomikan elemenelemen tersebut. Pada akhirnya, Insan kamil adalah sasaran pendidikan dalam Islam, dan ini dapat disasar dengan menggunakan paradigma humanisme religius.
\end{abstract}

Kata kunci: kapitalisme global, pendidikan Islam

Title: The Impact of Global Capitalism on Islamic Education

Author: Emawati

Abstract: The objective of this study is to find out how the impact of global capitalism on Islamic education. This research belongs to the category of library research. In data collection techniques, the researcher identified discourses from books, papers or articles, magazines, journals, web (internet), or other information related to the writing title to look for the things or variables in the form of notes, transcripts, books, newspapers, magazines and etc. The technique used in this thesis was the data analysis of Miles and Huberman model. The data analysis activities of this model included data reduction, data display and conclusion drawing/verification. The results of the study showed that religious humanism is as a paradigm, so that the orientation of Islamic education from elementary level to university level, formal, and informal needs to be directed to this point. With this paradigm, Islamic education, especially in Indonesian context (periferi), is expected to be able to prepare itself as a system which can be relied on preparing students who are ready to face all impacts caused by global capitalism which is controlled by Western countries (center). With this paradigm, the students can grow and develop all potentials that they have, while they keep the religious values. Thus Islamic education will not ignore the importance of physical and spiritual education and natural education; it does not dichotomize those elements. In the end, Insan Kamil (perfect buman) is the target of education in Islam, and it can be targeted by using the paradigm of religious bumanism.

Keywords: global capitalism, Islamic education 


\section{PENDAHULUAN}

Pembahasan mengenai kapitalisme global sebagai produk globalisasi ketika dikaitkan dengan pendidikan khususnya pendidikan Islam ${ }^{1}$ adalah satu hal yang sangat menarik. Penulis sependapat dengan Amin Abdullah, yang menegaskan bahwa dalam kegamangan meniti kehidupan era global yang amat kompleks, pendidikan masih merupakan alat yang dapat mencerahkan peradaban. Pendidikan keagamaan Islam yang terstruktur dan tersistimatisasi secara utuh, yang diharapkan dapat memberi peta yang utuh, lengkap dan komprehensif tentang keislaman amat diperlukan oleh warga masyarakat luas, termasuk para alumni perguruan tinggi umum, para penyelenggara negara dan para tokoh dan pemimpin gerakan sosial keagamaan. Kebutuhan mendesak itu muncul mengingat terjadinya kesimpangsiuran lalu lintas informasi tentang Islam dan klaim-klaim keislaman secara sepihak-subjektif, yang semakin hari semakin membingungkan masyarakat dan semakin tak terkontrol oleh siapapun dan oleh lembaga apapun. ${ }^{2}$

Azyumardi Azra menengarai bahwa era global dan globalisasi tidak terelakkan lagi dan menimbulkan perubahan penting dalam berbagai aspek dunia pendidikan. ${ }^{3}$ Lebih lanjut, Abd. Rahman Assegaf mengungkapkan bahwa pendidikan Islam di era global mengalami apa yang ia sebut dengan turbulensi arus global, yakni pergolakan yang ditimbulkan akibat modernisasi di segala bidang yang telah mendunia. ${ }^{4}$ Bagi pendidikan Islam, turbulensi arus global ini ini bisa menimbulkan paradoks atau gejala kontra moralitas ${ }^{5}$ antara apa yang diidealkan dengan relitas dalam kehidupan. Berbagai pendapat tersebut mengawali tulisan ini yang akan mencoba untuk menelaah kembali secara deskriptif-ekploratif, pengertian kapitalisme global dan pendidikan Islam, bagaimana dampak dari kapitalisme global sebagai wujud globalisasi

1 Menurut Tobroni, pengertian konsep "pendidikan Islam" seringkali mengundang keragaman arti bahkan perdebatan mengenai ada tidaknya pendidikan Islam, tampaknya masih menjadi persoalan hangat di kalangan para pemikir pendidikan Islam.Tobroni, Pendidikan Islam: Paradigma Teologis, Filosofis dan Spiritualitas (Malang: UMM Press, 2008), h. 13

${ }^{2}$ M. Amin Abdullah, "Islam Dan Modernisasi Pendidikan Di Asia Tenggara : Dari Pola Pendekatan Dikotomis-Atomistik Ke Arah Integratif-Interdisiplinary”, dalam http://aminabd.wordpress.com/2010/ 06/20/mempertautkan-ulum-al-diin-al-fikr-al-islamiy-dan-dirasat-islamiyyah-sumbangan-keilmuan-islamuntuk-peradaban-global/, diunduh pada tanggal 1 Mei 2014.

Bandingkan dengan pendapat John Dewey yang dikutip Tobroni, bahwa pendidikan adalah sebagai sebuah kebutuhan hidup (a necessary of life), salah satu fungsi sosial (social function), sebagai bimbingan ( $a$ direction), dan sebagai sarana prtumbuhan (as growth), yang mempersiapkan, dan membukakan serta membentuk disiplin hidup. Tobroni, Pendidikan Islam ..., h. 13.

3 Azyumardi Azra, Pendidikan Islam: Tradisi dan Modernisasi di Tengah Tantangan Milenium III, cet.ke-1 (Jakarta: Kencana Prenada Media, 2012), h. 51.

${ }_{4}^{4}$ Abd. Rachman Assegaf, Filsafat Pendidikan Islam: Paradigma Baru Pendidikan Hadhari Berbasis integratifinterkonektif, cet. ke-1 (Jakarta: Raja Grafindo Persada, 2011), h. 327.

${ }^{5}$ yakni pertentangan antara dua sisi moral secara diamentral, seperti guru mendidik lalu lintas, namun di jalanan para sopir ugal-ugalan, di sekolah anak didorong untuk kreatif, tapi perilaku orang tua cenderung otoriter dan sebagainya. 
baik dampak positif maupun dampak negatif, serta upaya yang dapat dilakukan pendidikan Islam dalam mengantisipasinya.

Kapitalisme global (global capitalism) dapat didefinisikan sebagai bentuk kapitalisme yang berskala global, yang terutama didukung oleh berbagai mekanisme-mekanisme struktural dan lembaga-lembaga multinasional. Karakteristik dari kapitalisme global ialah cakupannya yang mengglobal dan prinsip utamanya yaitu persaingan. ${ }^{6}$ Kapitalisme itu sendiri adalah sistem perekonomian yang menekankan peranan kapital atau modal. ${ }^{7}$

Habermas dalam Nuryatno, menyatakan bahwa kapitalisme saat ini adalah kapitalisme lanjut yang sangat berbeda dengan karakter kapitalisme liberal di masa Marx. Pandangan teori Marx memang sesuai dengan pemisahan peran negara dan pasar bebas di masanya. Akan tetapi, kapitalisme fase lanjut hari ini dijalankan justru melalui mekanisme dukungan dan proteksi negara. Negara dengan teknologinya dijadikan alat oleh kapitalisme untuk menjaga stabilitas dan melindungi keberlangsungan berjalannya industri-industri besarnya yang menjadi penyokong sistem ekonomi kapitalisme itu. Bahkan negara juga bertindak sebagai pelayan dan pelindung agenda para kapitalis global yang menjelma dalam wujud lembaga internasional dalam hal ini IMF, World Bank untuk sektor keuangan dan WTO, NAFTA dan AFTA untuk sektor perdagangan. ${ }^{8}$

Mansour Fakih, yang dikutip Nasrullah, mengemukakan tiga tahapan kapitalisme yakni kapitalisme liberal, developmentalisme, dan era kapitalisme global (globalisasi). Tahap awal ditandai dengan dibebaskannya pasar dan negara sebagai sekedar regulator. Ta hap kedua dikenal dengan penjajahan episteme dimana wacana pembangunan dan langkah-langkahnya di Indonesia termasuk skenario utang dan pembayaran serta regulasi-regulasi negara diatur oleh ketiga lembaga kapitalis global tersebut. Sedangkan fase terakhir yang sampai sekarang masih berjalan adalah negara menjadi penyedia regulasi dengan berbagai konsensus dengan tiga lembaga kapitalis tersebut, kemudian negara menjadi penjamin keberlangsungan sistem kapitalisme global tersebut dengan menyiapkan lahan yang dibutuhkan korporasi-korporasi global di berbagai sektor, termasuk BUMN dan PTN yang ada di Indonesia. ${ }^{9}$

Dominasi melalui utang dan hegemoni wacana investasi dan pertumbuban ekonomi dalam rangka menyerap tenaga kerja dan meningkatkan devisa dan Pendapatan Asli Daerah (PAD)

${ }^{6}$ http://paschall-ab.blogspot.com/2013/02/kapitalisme-global-dan-dehumanisasi.html, diunduh pada tanggal 5 Mei 2014.

7 http:/ / amadanwar.blogspot.com/2012/12/sistem-kapitalisme-global.html, diunduh pada tanggal 5 Mei 2014.

8 Analisis Hubermas sebagai teoritisi Frankfurt generasi kedua, dituangkan melalui Knowledge and Human Interest (1971), Nasrullah, "Telaah Kritis Dominasi dan Hegemoni Kapitalisme Global Pada Pendidikan Tinggi Indonesia" dalam http://law unhas.wordpress.com/2014/05/02/telaah-kritis-dominasi-dan-hegemonikapitalisme-global-pada-pendidikan-tinggi-indonesia/. diunduh pada tanggal 5 Mei 2014.

${ }^{9}$ Ibid. 
setelah wacana pembangunan berlalu adalah senjata utama dari kapitalisme global untuk mencengkram negeri ini. Demikian maka tidak berlebihan jika dikatakan bahwa globalisasi adalah satu bentuk yang lebih dahsyat dari imperialisme. Ia adalah bentuk baru dari moda penghisapan yang dilakukan kelas berkuasa terhadap rakyat miskin. 10

Pengertian istilah atau konsep "pendidikan Islam” seringkali mengundang keragaman arti. Pendidikan Islam, seringkali diartikan sebagai pendidikan dalam arti sempit, yaitu proses belajar mengajar dimana agama Islam menjadi core curicullum. Pendidikan Islam dapat pula berarti lembaga pendidikan yang di dalamnya terdapat kegiatan yang menjadikan Islam sebagai identitasnya, baik dinyatakan dengan semata-matanya atau tersamar. Perkembangan terakhir, pendidikan Islam diberi arti lebih substansial sifatnya, yaitu bukan sebagai proses belajar mengajar, maupun jenis kelembagaan, akan tetapi lebih menekankan sebagai suatu iklim pendidikan (education atmosphere), yaitu suatu suasana pendidikan yang islami, memberi nafas keislaman pada semua elemen sistem pendidikan yang ada. ${ }^{11}$

Islam sebagai sistem nilai universal dan diyakini mutlak kebenarannya seharusnya memberi paradigma filosofis dan teologis terhadap pendidikan Islam itu sendiri. Tetapi sayangnya, pengertian pendidikan Islam yang berkembang dalam masyarakat baru sekedar menerapkan etika Islam dalam pemanfaatannya, atau lebih sederhana lagi sebagai sebuah nama dari lembaga pendidikan yang dikelola oleh kaum Muslimin. Padahal, seharusnya pendidikan Islam adalah pengejawantahan nilai-nilai Islam dalam pendidikan baik secara ontologis, epistemologis dan aksiologis. ${ }^{12}$

Pendidikan Islam, sesuai cirinya sebagai pendidikan agama, secara ideal berfungsi dalam penyiapan SDM yang berkualitas tinggi, baik dalam penguasaan ilmu pengetahuan teknologi maupun dalam hal karakter, sikap moral, dan penghayatan dan pengamalan ajaran agama. Singkatnya, pendidikan Islam secara ideal berfungsi membina dan menyiapkan anak didik

\footnotetext{
${ }^{10}$ Sofyan Hadi, "Globalisasi dan Reformasi Evaluasi Kebijakan Pendidikan Yang Humanis dan Egaliter di Indonesia”, dalam Wahidul Anam dan Syaifullah, Implementasi Pendidikan Sains di Lembaga Pendidikan Islam (Kediri, STAIN Kediri- Nadi Pustaka Press, 2010), h. 172. Bandingkan dengan pendapat Azra, bahwa sumber globalisasi bagi masyarakat muslim Indonesia adalah Timur Tengah sejak abad ke-16 (Mekkah dan Madinah), dan sejak akhir abad ke-19 dan awal abad ke -20 juga Kairo. Globalisasi ini lebih bersifat religio-intelektual dan religio-politik. Sementara globalisasi yang berlangsung dan melanda masyarakat muslim sekarang ini menampilkan sumber dan sifat berbeda. Globalisasi dewasa ini bersumber dari Barat dengan watak ekonomipolitik dan sain-teknologi. Dominasi dan hegemoni ekonomi dan sain-teknologi Barat tetap belum tergoyahkan hingga saat ini meskipun berbagai negara besar Asia berusaha menyainginya. Azra, Pendidikan Islam..., h. 41.

${ }^{11}$ Tobroni, Pendidikan Islam: Paradigma Teologis, Filosofis dan Spiritualitas (Malang: UMM Press, 2008), h. 13. Bahkan seringkali pendidikan Islam lebih sempit lagi disamakan dengan Pendidikan Agama Islam, sebagai mata pelajaran meliputi Fiqih, Al-Qur'an, Hadits, Sejarah Islam, dan Akidah Akhlak.
}

${ }_{12}$ Ibid. 
yang berilmu, berteknologi, berketerampilan tinggi, dan sekaligus beriman dan beramal saleh. ${ }^{13}$

Sementara, problematika pendidikan Islam cukup kompleks sebagaimana permasalahan dunia Islam itu sendiri. Sebagaimana analisis Fazlur Rahman, dalam Abdurrahman Mas'ud, bahwa problematika itu meliputi social institution dan social ethic. Pranata sosial antara lain adalah lembaga-lembaga pendidkan Islam yang sudah berabad-abad tidak mampu menandingi supremasi schooling dunia Barat. Maka perlu mempertimbangkan slogan think globally act locally 'berpikir secara mondial dan betindak secara lokal'. Sedangkan persoalan social ethic dalam pendidikan Islam menyangkut beberapa hal, antara lain: pertama, adanya pandangan mengenai kecenderungan dikotomis dan polaris antara ilmu agama dan ilmu umum. Kedua, adanya perlakuan terhadap anak didik yang dianggap sebagai objek, bukan subjek. Ketiga, lemahnya spirit of inquiry karena dominasi sistem hafalan. ${ }^{14}$

\section{METODE PENELITIAN}

\section{Jenis Penelitian}

Penelitian ini merupakan penelitian kualitatif. Sesuai dengan obyek kajian ini, maka jenis penelitian ini termasuk dalam kategori penelitian kepustakaan (library research), yaitu, pertama, dengan mencatat semua temuan mengenai motivasi konsumsi secara umum pada setiap pembahasan penelitian yang didapatkan dalam literatur-literatur dan sumber-sumber, dan atau penemuan. Setelah mencatat, kedua, memadukan segala temuan, baik teori atau temuan baru.Ketiga, menganalisis segala temuan dari berbagai bacaan, berkaitan dengan kekurangan tiap sumber, kelebihan atau hubungan masing-masing tentang wacana yang dibahas di dalamnya. Terakhir adalah mengkritisi, memberikan gagasan kritis dalam hasil penelitian terhadap wacana-wacana sebelumnya dengan menghadirkan temuan baru dalam mengkolaborasikan pemikiran-pemikiran yang berbeda. Menurut Kaelan, dalam penelitian kepustakaan kadang memiliki deskriptif dan juga memiliki ciri historis. ${ }^{15}$.Dikatakan historis karena banyak penelitian semacam ini memiliki dimensi sejarah, termasuk di dalamyna penelitian agama, misalnya tentang karya tokoh pemikir keagamaan masa lalu Penelitian kepustakaan ini bisa meliputi kritik pemikiran, penelitian sejarah agama, dan dapat pula penelitian tentang karya tertentu atau naskah tertentu. ${ }^{16}$ Oleh karenanya penelitian kepustakaan akan menghadapi sumber data berupa buku-buku yang jumlahnya sangat banyak sehingga memerlukan motode yang memadai. Untuk itu dalam penelitian kepustakaan,

${ }^{13}$ Azra, Pendidikan Islam..., h. 64.

${ }_{14}^{14}$ Abdurrahman Mas'ud dalam bukunya Menggagas Format Pendidikan Non-Dikotomik: Humanisme Religius sebagai Paradigma Pendidikan Islam (Yogyakarta: Gama Media, 2002). h. 221-224.

${ }^{15}$ Kaelan, Metode Penelitian Agama Kualitatif Interdisipliner (Yogyakarta: Paradigma, 2010)

16 Ibid. 
mengumpulkan buku harus secara bertahap, sebab akan kesulitan apabila tidak demikian. Untuk mendapatkan segala kebutuhan tersebut di atas, bisa dihasilkan melalui perpustakaa, toko buku, maktabah syamilah, pusat penelitian dan jaringan internet atau yang lainnya. Dengan menggunakan data-data dari berbagai referensi baik primer maupun sekunder. Datadata tersebut dikumpulkan dengan teknik dokumentasi, yaitu dengan jalan membaca (text reading), mengkaji, mempelajari, dan mencatat literatur yang ada kaitannya dengan masalah yang dibahas dalam tulisan ini.

\section{Teknik Pengumpulan Data}

Teknik pengumpulan data, dalam hal ini penulis melakukan identifikasi wacana dari buku-buku, makalah atau artikel, majalah, jurnal, web (internet), ataupun informasi lainnya yang berhubungan dengan judul penulisan untuk mencari hal-hal atau variabel yang berupa catatan, transkip, buku, surat kabar, majalah dan sebagainya. Maka dilakukan langkah-langkah sebagai berikut:

a. Mengumpulkan data-data yang ada baik melalui buku-buku, dokumen, majalah internet (web).

b. Menganalisa data-data tersebut sehingga peneliti bisa menyimpulkan tentang masalah yang dikaji.

Pada hakikatnya tidak ada acuan khusus dalam mengumpulkan data pada metode ini, namun tidak dengan begitu saja data yang dikumpulkan dijadikan hasil penelitian, karena akal manusia memberikan bimbingan pekerjaan secara sistematis dan sesuai dengan objek kajiannya. Oleh karenanya perlu teknik tertentu agar hasil penelitian sifatnya sistematis dan objektif. Dua instrument penelitian digunakan dalam pengumpulan data ini, pertama, pengumpulan data dalam bentuk verbal simbolik, yaitu mengumpulkan naskah-naskah yang belum dianalisis. Dalam pengumpulan data ini peneliti bisa menggunakan alat rekam, seperti fotocopy dan lain sebagainya. Kedua, kartu data yang berfungsi untuk mencatat hasil data yang telah didapat untuk lebih memudahkan peneliti dalam mengklarifikasi data yang telah didapatkan di lapangan, selain itu pula kartu data memberikan solusi jika instrumen pertama sulit untuk dioperasionalkan, kartu data bisa digunakan sebagai pengganti dari instrument pertam, namun dengan konsekuensi lamanya waktu berada di lokasi sumber data. Pertamatama yang harus dilakukan dalam pengumpulan data adalah menentukan lokasi pencarian sumber data, seperti perpustakaan dan pusat-pusat penelitian. Setelah menentukan lokasinya, mulai mencari data yang diperlukan dalam penelitian. Data yang kemudian didapatkan dilokasi akan dibaca oleh seorang peneliti, karena tugas utama peneliti adalah mampu menangkap makna yang terkandung dalam sumber kepustakaan tersebut. Oleh karena itu ada dua tahap dalam membaca data yang telah diperoleh. 
a. Membaca pada tingkat simbolik. Seorang peneliti tidak mungkin akan membaca seluruh sumber yang didapatkan dari pertama hingga akhir. Jika itu dilakukan, maka akan menyita waktu dan akan mengurangi efisiensi waktu penelitian. Tahap ini ialah dengan tidak membaca secara keseluruhan melainkan dengan menangkap sinopsis dari buku, bab, subbab sampai pada bagian terkecil dari buku, hal ini sangat penting dilakukan untuk mengetahui peta penelitian, hasilnya akan dicatat dalam kartu data dan diberikan kode sesuai dengan peta dan kategori penelitian yang dilakukan.

b. Membaca pada tingkat semantik. Membaca data yang telah dikumpulkan dengan lebih terperinci, terurai dan menangkap esensi dari data tersebut. Hal ini membutuhkan ketekunan dan waktu yang cukup lama. Tiap poin yang dibaca dilakukan analisis dalam data tersebut. Peneliti harus mendahulukan data yang bersifat primer, jika sudah dianggap cukup selanjutnya mengumpulkan data yang bersifat sekunder. Setelah membaca secara semantik dilakukan, dicatat dalam kartu data, tahapan pencatatan dalam kartu ada di antaranya:

1) Mencatat secara qoutasi, yaitu dengan mencatat kutipan langsung tanpa merubah sedikitpun redaksi sumber data atau dari penulis karya tersebut, biasanya untuk mencatat terminologi-terminologi kunci untuk mengembangkan interpretasi yang lebih luas.

2) Mencatat secara paraphrase, dengan menangkap intisari dari data dengan redaksi kata yang disusun oleh peneliti sendiri. Proses ini bisa dilakukan dengan analisis verstehen untuk menagkap intisari dari data yang berupa uraian panjang lebar, lalu diambil intisari pemahaman dari uraian panjang tersebut menjadi kalimat singkat dan padat agar dengan mudah terekam pada kartu data.

3) Mencatat secara sinoptik, mencatat model ini lebih pada ringkasan, artinya setelah membaca bagian atau sub bagian data kategori tertentu, kemudian peneliti membuat ringkasan atau sinopsis yang harus benar-benar persis sama secara logis dari data yang dibaca.

4) Mencatat secara presis. Mencatat model ini adalah kelanjutan dari mencatat secara sinoptik. Seletah mencatat secara sinoptik, peneliti akan menghadapi hasil dari catatan sinoptik yang banyak, maka perlu pengkategorian catatan, misalnya unsur nilai agama, nilai budaya, epsitemologi, aksiologi, etika dan unsur-unsur lainnya. Peneliti lebih lanjut membuat catatan yang lebih padat lagi berdasarkan pada catatan sinoptik yang terkumpul.

5) Pengkodean. Tahap ini adalah tahap yang paling teknis dalam sebuah penelitian, tujuannya mensistematiskan agar data yang tidak teratur atau yang bertumpuk. Melalui kartu data, data dipilih sesuai dengan kategori data masing-masing dan tokoh yang tercantum dalam data tersebut, termasuk penerbit dan tempatnya. 
Memberikan kode pada nama tokoh, pembahasannya epistemology (EP), jenisnya sumber pengetahuan (sub. Peng), masing-masing ditulis di sisi kanan, tengah dari kiri atas kartu data, begitu seterusnya dengan data lain.

\section{Analisis Data}

Teknik yang digunakan dalam tesis ini adalah analisis data model Miles dan Huberman. Dalam model ini aktifitas analisis kualitatif dilakukan secara interaktif dan terus-menerus sampai dirasa cukup. Menurut Kaelan, ada dua tahap dalam teknik analisis data pada penelitian kepustakaan ini. Pertama, analisis pada saat pengumpulan data, ini ditujukan untuk lebih menangkap esensi atau inti dari fokus penelitian yang akan dilakukan melalui sumbersumber yang dikumpulkan dan terkandung dalam rumusan verbal kebahasaan, proses ini dilakukan aspek demi aspek, sesuai dengan peta penelitian. Kedua, setelah dilakukan proses pengumpulan data itu, selanjutnya menganalisis kembali setelah data terkumpul yang berupa data mentah yang harus ditentukan hubungan satu sama lain. Data yang terkumpul tersebut belum tentu seluruhnya menjawab permasalahan yang dimunculkan dalam penelitian, oleh karena itu perlu dilakukan kembali analisis data yang sudah diklarifikasikan tersebut. Aktifitas analisis data model ini antara lain, reduksi data (data reduction), display data dan gambaran konklusi atau verifikasi (conclusion drawing/verification).

\section{Validasi Data}

Validasi data setidaknya ditentukan menggunakan tiga kategori, pertama, kepercayaan, kredibilitas seseorang peneliti sangat dipertanyakan apakah data tepat dalam fokusnya, ketepatan memilih informan dan pelaksanaan motode pengumpulan datanya. Analisis data dan interpretasi data, seluruhnya membutuhkan konsistensi satu sama lain. Kedua, keteralihan (transferbility) hasil penelitian yang dikemudian hari dijadikan rujukan kembali pada penelitian yang setema dan dipelajari lebih lanjut oleh peneliti lain. Jika seorang peneliti memahami dan mendapat gambaran yang jelas terhadap hasil penelitian sebelumnya, maka hasil penelitian tersebut sudah memenuhi standar transferbilitas. Ketiga, kebergantungan penelitian terhadap data yang didapatkan, dengan kata lain penelitian adalah hasil rekam jejak dari data yang telah ditelusuri di lapangan. Keempat, kepastian, adalah menguji keabsahan hasil penelitian terhadap kasus atau fenomena yang sudah terjadi dilapangan baik secara teoritis atau aplikatif, jika hal tersebut terbukti, maka hasil penelitian bisa dikatakan absah.

\section{HASIL PENELITIAN DAN PEMBAHASAN}

\section{Pendidikan Islam dalam Konteks Indonesia}

Pendidikan Islam dalam pengertian seluas-luasnya tersebut bagaimanapun juga tidak dapat dilepaskan dari konteks yang melingkupinya, dalam hal ini yang dimaksud adalah dalam 
konteks nasional- Indonesia. Penyempitan lingkup kelembagaan pendidikan Islam juga perlu diluruskan. Dengan menggunakan pendekatan substantif,-bukan pendekatan formal tekstual-, substansi pendidikan nasional relevan dengan pendidikan Islam. Hal ini misalnya dapat difahami dalam Undang-Undang Sisdiknas No. 20 tahun 2003, pasal 2 dan 3. Pasal 2: "Pendidikan nasional berdasarkan Pancasila dan Undang-Undang Dasar 1945"; pasal 3: "Pendidikan nasional berfungsi mengembangkan kemampuan dan membentuk watak serta peradaban bangsa yang bermartabat dalam rangka mencerdaskan bangsa, bertujuan untuk berkembangnya potensi peserta didik agar menjadi Tuhan Yang Maha Esa, berakhlak mulia, sehat, berilmu, cakap, kreatif, mandiri dan menjadi warga negara yang demokratis serta bertanggung jawab".

Menurut Achmadi, relevansi substansi antara pendidikan nasional dengan pendidikan Islam terletak pada; pertama, nilai-nilai yang terkandung dalam Pancasila sebagai dasar pendidikan tidak bertentangan dengan nilai-nilai dasar Islam (Tauhid); kedua, pandangan terhadap manusia sebagai makhluk jasmani-ruhani yang berpotensi untuk menjadi manusia bermartabat (makhluk paling mulia); ketiga, pendidikan bertujuan untuk mengembangkan potensi (fitrah dan sumber daya manusia) menjadi manusia beriman dan bertakwa kepada Tuhan Yang Maha Esa, berbudi luhur (akhlak mulia) dan berbagai kemampuan untuk memikul tanggung jawab (sebagai khalifatullah). ${ }^{17}$

Ditinjau dari tataran universalitas, konsep Islam lebih universal karena tidak dibatasi negara dan bangsa, tetapi ditinjau dari posisinya dalam konteks nasional konsep pendidikan Islam menjadi subsistem pendidikan nasional. Sebagai subsistem, pendidikan Islam berfungsi sebagai penunjang pendidikan nasional, sebaliknya pendidikan nasional sebagai sistem mengakses kepentingan pendidikan Islam. Dalam konteks inilah, maka problema pendidikan nasional (baca: pendidikan Islam di dalamnya) dalam perspektif global, tidak mungkin diselesaikan oleh sekelompok masyarakat baik kelompok etnis maupun agama tertentu, begitu pula oleh LSM maupun pemerintah.

Dalam konteks inilah, menurut hemat penulis, analisis Azra tepat, bahwa teori centerperiferi, yang belakangan ini seolah-olah kehilangan pamornya, ternyata masih relevan untuk menggambarkan dinamika globalisasi yang tidak seimbang antara Barat dengan masyarakat masyarakat muslim, termasuk kaum muslim Indonesia. Barat, lebih khusus Amerika, adalah "center" (pusat) yang menjadi acuan, dan masyarakat-masyarakat muslim adalah "perifer" (pinggiran) yang kurang atau tidak, akan terseret ke pusat, dengan biaya sosio-kultural yang tidak sedikit. ${ }^{18}$

${ }_{17}$ Achmadi, Ideologi Pendidikan Islam (Yogyakarta: Pustaka Pelajar, ), h. 184.

18 Azra, Pendidikan Islam..., h., 45. Yang terjadi sebenarnya adalah "imperialisme kultural" (cultural imperialism) pusat terhadap wilayah periferi. 
Namun demikian, dalam makalah ini, penulis akan mencoba menawarkan kembali (formulasi yang telah digagas beberapa tokoh pendidikan) sebagai suatu upaya yang dapat dilakukan oleh masyarakat muslim (baca: pendidikan Islam) di Indonesia sebagai komunitas periferi dalam mengahadapi dampak kapitalisme global yang aktor utamanya adalah negaranegara "center" tersebut. Upaya yang dimaksud adalah upaya yang bersifat paradigmatik yakni konsep humanisme religius yang dapat dipraktikkan dalam pendidikan Islam, didasarkan atas analisis dampak positif dan dampak negatif dari kapitalisme global, dengan harapan tidak menyempitkan arti pendidikan Islam.

\section{Dampak Positif Kapitalisme Global terhadap Pendidikan Islam}

Kapitalisme global sebagai wujud globalisasi sudah barang tentu tidak hanya memiliki kesan negatif, namun juga mengindikasikan beberapa hal positif terhadap pendidikan Islam, dalam arti seluas-luasnya. Beberapa dampak positif sebagai peluang di antara tantangan kapitalisme global adalah:

1. Potensial 'membebaskan'.

Kecenderungan globalisasi yang memunculkan gejala otonomisasi, devolusi dan desentralisasi sesungguhnya potensial untuk 'membebaskan' sekolah dari macam-macam belenggu, seperti sentralisme, uniformisme, monolitisme, dan desentralisasi. Pada tingkat pendidikan dasar dan menengah, pemerintah lokal dan masyarakat lokal semakin memainkan peranan lebih besar dalam merancang dan menyelenggarakan pendidikan. Pada pendidikan tingkat tinggi, terjadi peningkatan otonomisasi dan privatisasi, di mana peranan pemerintah semakin mengecil, dan peranan stake holders semakin besar. ${ }^{19}$ Dengan demikian, pendidikan dapat menjawab berbagai tantangan yang dihadapi masyarakat masing-masing.

Pada sisi lain, sebagaimana diidealkan oleh Paulo Freire dan Ivan Illich ${ }^{20}$, peserta didik juga 'bebas' dari sekedar sebagai objek dari apa yang yang disebut sebagai banking concept of education, di mana peserta didik diposisikan sebagai orang yang tidak tahu apa-apa sama sekali, dan karena itu harus dijejali para guru sesuai kemampuannya sendiri. ${ }^{21}$

2. Peningkatan demokratisasi dan equity dalam pendidikan

Pembelajaran yang berlangsung dengan memberikan peluang lebih besar kepada peserta didik untuk mengekspresikan diri mereka, pada gilirannya menumbuhkan iklim demokratis di lingkungan pendidikan. Dengan demikian, maka sekolah menjadi sarana penting bagi penanaman nilai demokrasi itu sendiri dalam diri peserta didik. Guru pada saat yang sama,

19 Azra, Pendidikan Islam..., h. 51.

${ }^{20}$ Freire menawarkan gagasan pedagogy of the oppressed, sedangkan Illich menawarkan perlunya deschooling, penghapusan sekolah, yang menurut Azra juga tidak realistis.

21 Azra, Pendidikan Islam..., h. 56. 
tidak lagi satu-satunya pemegang monopoli dalam proses belajar. Guru seharusnya lebih siap mendengar dan memberi kesempatan 'berbicara kritis' kepada peserta didik. ${ }^{22}$

\section{Akselerasi Ilmu Pengetahuan}

Global Brain memungkinkan akselerasi perkembangan ilmu pengetahuan dan teknologi di dunia. Dunia penelitian, bisnis, industri dimungkinkan untuk menggunakan sumber daya manusia maupun fasilitas lainnya tanpa terikat pada dimensi-dimensi ruang dan batas-batas negara. ${ }^{23}$ Kecanggihan sarana telekomunikasi dan teknologi informasi yang terus berkembang mendukung kemudahan akses referensi ilmiah yang dibutuhkan dalam dunia akademik.

\section{Penyederhanaan kurikulum}

Subyek yang dipandang tidak terlalu penting dan tidak relevan dengan kebutuhan global dihilangkan dari kurikulum. Sebaliknya, subyek-subyek yang urgen dan instrumental bagi peserta didik dalam menghadapi realitas globalisasi, semakin mendapat penekanan penting atau bahkan diprioritaskan. ${ }^{24}$ Dengan demikian maka kurikulum menjadi lebih sederhana.

\section{Dampak Negatif terhadap Pendidikan Islam}

Kapitalisme global, disamping memiliki dampak positif, sebagaimana dikemukakan di atas, sudah barang tentu juga mempunyai dampak negatif terhadap pendidikan termasuk pendidikan Islam. Beberapa dampak negatif tersebut diuraikan berikut:

1. Pendidikan bersifat kapitalistik.

Pendidikan mengarah kepada industrialisasi. Pendidikan seolah pabriknya buruh, mengabdi pada kepentingan industri bukan untuk mengembangkan keilmuan dan peradaban manusia dalam upaya menata masa depannya. Sekolah misalnya, hanya untuk mencari kerja, atau lebih eksplisit mencari uang. ${ }^{25}$

Pengaruh dunia industri terhadap pendidikan adalah penyamaan antara proses pendidikan dengan proses produksi dengan pola input-proses- output. Anak didik diibaratkan sebagai raw input, sementara komponen pendidikan lain seperti guru, kurikulum dan fasilitas pendidikan dianggap sebagai komponen produksi dalam suatu pabrik. Output yang baik adalah output yang dikehendaki oleh pasar terutama dunia industri dan politik. Pendidikan dengan demikian memandang manusia secara parsial yaitu sebagai makhluk. Sementara,

22 Ibid, h. 57.

23 http://www.kompas.com/kompas-cetak/0304/28/nasional/280846.htm, diunduh pada tanggal 4 Mei 2014.

24 Azra, Pendidikan Islam..., h. 52.

25 Sofyan Hadi," Globalisasi...”, h. 185. 
dampak dari pendidikan yang terlalu material oriented seperti demikian, dapat berkibat pada pelanggaran nilai-nilai kemanusiaan yang dijunjung tinggi oleh humanisme. ${ }^{26}$

Pendidikan dalam konsep industrialisasi akan memberikan solusi bagi manusia pada pilihan-pilihan mekanistik. Industrialisasi telah memenjarakan pada pemaknaan-pemaknaan baru sehingga tingkat kesadaran manuasia atas posisi di semesta terekayasa oleh kepentingan interpretasi industrialisasi. Bila nama, istilah, dan simbol dimaknai secara mekanistik, maka makna-makna ini akan mengikat manusia pada dunia baru yang serba materialistis. Dengan demikian, maka kehormatan manusia dihargai dari berapa besar materi yang dihasilkannya. Kehidupan menjadi diskriminatif, karena diskriminasi adalah konsekuensi dari simbol kemajuan industrialisasi. ${ }^{27}$

2. Privatisasi pendidikan atau swastanisasi pendidikan.

Salah satu sektor jasa yang menjadi korban liberalisasi dan privatisasi adalah sektor pendidikan yang ditelurkan melalui perjanjian GATT (General Agreements on Tariff and Trade) pada tahun 1994 bersama berbagai sektor jasa lain yang ikut diliberalisasi dan diprivatisasi, termasuk kesehatan. Regulasi yang telah didiktekan oleh WTO untuk meliberalisasi dan memprivatisasi pendidikan Indonesia dimulai dengan disahkannya UU Sisdiknas ${ }^{28}$ yang salah satu pasalnya mewajibkan Pendidikan Indonesia berbentuk Badan Hukum kemudian BHP dengan semangat otonomi dan pembukaan ruang kepada publik (masyarakat dan industri) untuk menjadi penyedia dana pendidikan, dan setelah dibatalkan oleh MK, maka tahun 2012 kemarin lahirlah UU Pendidikan tinggi yang tetap memiliki semangat yang sama yakni semangat liberalisasi yang memberi ruang pada sektor swasta dan industri untuk menjadi penyedia dana (investasi) di dunia pendidikan. ${ }^{29}$

26 Abdurrahman Mas'ud, Pengantar dalam Tobroni, Pendidikan Islam: Paradigma Teologis, Filosofis dan Spiritualitas (Malang: UMM Press, 2008), h. viii.

${ }^{27}$ Agus Zainul Fitri, "Desain Kurikulum Pondok Pesantern Modern Unggulan: Upaya Meminimalisasi Industrialisasi dan Kapitalisasi Pendidikan" dalam Wahidul Anam dan Syaifullah, Implementasi Pendidikan ..., h. 250.

${ }^{28}$ Hal ini juga nampak dalam Undang-Undang Sistem Sistem Pendidikan Nasional No 20/2003, Pasal 53 ayat 1 yaitu : " penyelengaraan dan/atau satuan pendidikan formal yang didirikan oleh pemerintah atau masyarakat berbentuk badan hukum pendidikan". Pasal ini kemudian ditindaklanjuti dengan adanya RUU BHP yang menuai kontroversi. RUU BHP berisi antara lain, melepaskan perguruan tinggi dari intervensi pemerintah (dalam aspek manajemen administrasi keuangan, sumber daya manusia, dan akademik). Bahkan perguruan tinggi juga bebas bekerjasama dengan institusi asing. Dan yang menjadi penolakan adalah bila pemerintah melepaskan tanggungjawabnya atas pembiayaan pendidikan. Sofyan Hadi,” Globalisasi...", h. 188189.

29 Nasrullah, "Telaah Kritis..... . Dampaknya adalah dari segi statistic Mendiknas hanya mampu menargetkan $33 \%$ partisipasi atau daya tampung Anak Negeri lulusan SMA dan sederajat tahun depan (2015) untuk masuk Perguruan Tinggi. Dan selebihnya $67 \%$ akan tersisih. Sementara itu dengan kualitas pendidikan dan ketersediaan akses dalam bekerja angka 7,17 juta warga Negara menjadi pengangguran dari data yang sempat dicatat oleh BPS tahun 2013, 360 ribu diantaranya adalah lulusan Perguruan Tinggi. 


\section{Dampak lanjutan}

Apabila pemerintah membiarkan privatisasi pendidikan terus berkembang tanpa adanya kebijakan dan regulasi yang tepat maka dampak berikutnya adalah: (1) lembaga-lembaga pendidikan yang didirikan dengan menggunakan uang rakyat hanya akan dinikmati oleh sekelompok kecil masyarakat mampu, (2) masyarakat miskin hanya bisa mengakses pendidikan di sekolah-sekolah murah yang pada umumnya berkualitas rendah, (3) akibat pendidikan yang tidak berkualitas, masyarakat miskin tidak akan dapat bersaing dengan orang-orang kaya yang memperoleh pendidikan dengan kualitas yang jauh lebih baik, dan (4) akibat selanjutnya, anak dari keluarga miskin akan sulit keluar dari kemiskinannya. ${ }^{30}$

\section{Humanisme-Religius Vs Kapitalisme Global ${ }^{31}$}

Berdasarkan uraian mengenai berbagai dampak positif dan dampak negatif dari kapitalisme global di atas kaitannya dengan realitas dalam dunia pendidikan Islam saat ini, maka perlu adanya upaya konseptual yang dimungkinkan untuk dapat menghilangkan atau setidaknya meminimalisir atau dalam istilah Azra memberikan respon yang tepat terhadap dampak negatif tersebut dalam konteks pendidikan Islam -khususnya di Indonesia-. Salah satu upaya yang dimaksud adalah dengan menerapkan paradigma humanisme-religius dalam pendidikan Islam, pada setiap komponennya. ${ }^{32}$

Paradigma humanisme religius dipandang sesuai untuk menjawab tantangan kapitalisme global dengan asumsi bahwa dengan penerapan paradigma tersebut pada pendidikan Islam maka pendidikan Islam tidak tergilas oleh dampak-dampak negatif yang ditimbulkan globalisasi. Atau dalam ungkapan Amin Abdullah, bahwa umat Islam tidak boleh berpangku tangan dan menonton dari luar seluruh perkembangan yang terjadi di era globalisasi ini. ${ }^{33}$

Pendidikan Islam saat ini lebih banyak menawarkan konsep "bagaimana untuk menjadi" bukan "mengapa harus menjadi”. ${ }^{34}$ Dari sini nampak bahwa pendidikan membingkai anak didik sebagai makhluk pasif, bukan makhluk aktif, yang dapat mengidentifikasi, mengklasifikasi, dan memverifikasi dunia dalam imajinasinya. Bila pendidikan mengabaikan manusia sebagai makhluk aktif maka pendidikan tidak akan mampu mengakomodasi

\footnotetext{
${ }^{30}$ Sofyan Hadi," Globalisasi...”, h. 190.

31 Versus di sini bukan dalam pengertian "law an bermusuhan", tetapi dalam arti “upaya menghadapi"

32 Gagasan ini pernah juga ditawarkan Abdurrahman Mas'ud dalam bukunya Menggagas Format Pendidikan Non-Dikotomik: Humanisme Religius sebagai Paradigma Pendidikan Islam (Yogyakarta: Gama Media, 2002). Sementara Azra menawarkan paradigma parsipatoris dalam pendidikan Islam sebagai respon yang tepat terhadap globalisasi.

33 Salah satu wujud pemikirannya adalah pengembangan IAIN menjadi UIN dengan visi baru program reintegrasi epistemologi keilmuan yakni jaring laba-laba keilmuan Teoantroposentrik-Integralistik.

${ }^{34}$ Bandingkan dengan pendidikan di Barat yang mengedepankan pendidikan rasional dan pendidikan why, menumbuhkan curiousity sejak dini.
} 
keutuhan manusia atas kemanusiaannya. Pendidikan seperti ini akan mengarahkan manusia yang serba pragmatis karena dituntut untuk mendapatkan identitas atau gelar sebagai simbol keahliannya dan keilmuannya dalam bidang tertentu namun tidak menyadari mengapa harus memiliki identitas seperti itu. ${ }^{35}$

Sementara, identitas tidak akan menjawab masalah manusia bila identitas sendiri tidak menjamin manusia bisa memenuhi kebutuhan di tingkat idealitasnya. Hal ini terjadi karena identitas yang dihasilkan tidak didapatkan dari proses pendidikan yang seutuhnya, yakni pendidikan yang melibatkan aspek pasif dan aktif dari diri manusia sehingga manusia mampu memposisikan dirinya sebagai makhluk yang utuh. Selanjutnya, keutuhan inilah yang akan mempengaruhi persepsi manusia atas dirinya terhadap semesta dan menjadi titik tolak bagi manusia untuk membebaskan dirinya dari belenggu yang menyekat fitrahnya (sebagai seorang hamba dengan spesifikasi potensi tertentu). ${ }^{36}$ Dalam konteks inilah maka pembaharuan paradigma dalam pendidikan Islam menjadi satu hal yang urgen untuk segera diterapkan. Paradigma humanisme religius merupakan paduan paradigma yang menurut penulis sesuai untuk diterapkan dalam pendidikan Islam baik dalam konteks khusus Indonesia maupun konteks umum seluruh kawasan muslim dalam rangka menghadapi dampak kapitalisme global saat ini. Artinya, dengan upaya yang bersifat menguatkan kapasitas dari dalam dirinya, pendidikan Islam, akan mampu menunjukkan eksistensinya dan mengikuti perkembangan zaman.

Istilah pendidikan humanis-religius mengandung dua konsep pendidikan yang ingin diintegrasikan, yaitu pendidikan humanis dan pendidikan religius. Pendidikan humanis yang menekankan aspek kemerdekaan individu diintegrasikan dengan pendidikan religius agar dapat membangun kehidupan individu (sosial) yang memiliki kemerdekaan, tetapi dengan tidak meninggalkan (sekuler) nilai-nilai keagamaan yang diikuti masyarakat atau menolak nilai ketuhanan (ateisme). ${ }^{37}$

Konsep humanisme religius dalam pendidikan, menurut Abdullah Mas'ud, adalah konsep keagamaan yang menempatkan manusia sebagai manusia, serta upaya humanisasi ilmu-ilmu dengan tetap memperhatikan tanggung jawab hablum minallah dan hablum minannas. Konsep ini jika dimplementasikan dalam praktik dunia pendidikan Islam akan berfokus pada akal sehat (common sense), individualisme menuju kemandirian dan tanggung jawab, thirts for knowledge, pendidikan pluralisme kontekstualisme yang lebih mementingkan fungsi dari pada simbol, serta keseimbangan antara reward and punishment. ${ }^{38}$ Pada intinya, menuju pada proses

35 Zainul Fitri, “Desain Kurikulum ...”, h. 251.

36 Ibid. 3.

${ }^{37}$ Agus Sutiyono, “Sketsa Pendidikan Humanis Religius” dalam Jurnal Insania, Vol. 1, No. 2, 2009, h. 38 Mas’ud, Menggagas ..., h. 194. 
pendidikan yang lebih memperhatikan aspek potensi manusia sebagai makhluk sosial dan makhluk religius, 'abdullah dan khalifatullah. 39

Beberapa alasan menggunakan paradigma ini adalah bahwa: pertama, adanya keberagamaan yang cenderung menekankan hubungan vertikal dan kesemarakan ritual. Kedua, akibat dari fenomena tersebut maka kesalehan sosial agaknya masih jauh dari orientasi masyarakat kita. Ketiga, potensi peserta didik belum dikembangkan secara proporsional, pendidikan belum berorientasi pada pengembangan sumber daya manusia, atau belum indivudual-oriented. Keempat kemandirian anak didik dan tanggung jawab (responsibility) masih jauh dari capaian duna pendidikan. ${ }^{40}$

Sejalan dengan gagasan tersebut adalah konsep yang dilontarkan Achmadi dengan tawaran konsep humanisme teosentris. Islam sebagai agama fitrah memiliki konsep humanisme yang secara eksplisit berbeda dengan prinsip-prinsip filsafat, ideologi, dan agamaagama lain. Humanisme Islam adalah humanisme teosentris, yakni pandangan kemanusiaan tetap dalam bingkai keimanan kepada Tuhan Yang Maha Esa (taubid). Oleh karena itu, humanisme teosentris merupakan nilai inti (core of value) dari seluruh sistem nilai dalam Islam. Islam tidak menegasikan pemikiran rasio dalam teologinya, tetapi Islam justru menekankan pentingnya penggunaan daya-daya indra, akal dan hati untuk menemukan kebenaran. Teosentrisme yang dimaksud di sini adalah taubidi, yaitu bahwa seluruh kehidupan berpusat pada Allah, Tuhan Yang Maha Esa. ${ }^{41}$

\section{Strategi Pendidikan Berparadigma Humanisme Religius}

Mas'ud merekomendasikan untuk mengimplementasikan konsep humanisme-religius ini dalam praktik pendidikan Islam pada semua aspek dalam pendidikan, aspek guru, materi, peserta didik, keluarga, dan termasuk pada aspek evaluasi pendidkan. ${ }^{42}$ Guru harus memiliki tiga kualifikasi dasar, menguasai materi, antusiasme dan penuh kasih sayang dalam mengajar dan mendidik. Misi utama guru adalah enlightening, mencerdaskan bangsa, bukan menjadikannya manja dan beban masyarakat. ${ }^{43}$ Metode diarahkan pada pepatah 'berilah kail jangan beri ikan". Meode guru harus menggunakan paradigma baru yang menekankan kreativitas, penajaman hati nurani dan religiusitas siswa, dan meningkatkan kepekaan sosialnya.

${ }^{39} \mathrm{Ibid}$, h. 135. Lebih lanjut ia mengungkapkan bahwa konsep ini, jika diterapkan dalam praktik dunia pendidikan Islam akan terfokus pada akal sehat, individualisme menuju kemandirian dan tanggungjawab, thirts for knowledge, pendidikan pluralisme, kontekstualisme yang lebih mementingkan fungsi daripada simbol, serta keseimbangan antara reward dan punishment.

40 Mas'ud, Menggagas..., h. 143-153.

${ }^{41}$ Achmadi, Ideologi Pendidikan Islam (Yogyakarta: Pustaka Pelajar, ), h. 23-24.

42 Mas'ud, h. 191-212.

${ }^{43}$ Ibid, h. 194-196 
Sementara, peserta didik hendaknya diarahkan pada semangat thirts for knowledge dan "individualisme" sebagai sikap dasar yang dilandasi oleh semangat keagamaan sehingga spirit of inquiry-nya terbangun dengan pandangan yang tidak dikotomis. ${ }^{44}$ Demikian juga, kurikulukum perlu disederhanakan sebagaimana tuntutan sekaligus dampak positif kapitalisme global. Hal ini karena kurikulum pada pendidikan Islam pada umumnya masih bersifat overload, sehingga yang terjadi paserta didik memperoleh kelelahan yang berlebihan dan peserta didik akan kekeringan kretifitas. ${ }^{45}$

Evaluasi perlu menggunakan dua arah yakni peserta didik dievaluasi oleh guru dan sebaliknya. Evaluasi terhadap peserta didik juga seimbang pada aspek kognitif, afektif dan psikomotor secata kontinyu, harian bukan hanya setiap akhir semester. ${ }^{46}$ Berbagai perbaikan unsur pendidikan dengan menggunakan paradigma humanisme religius tersebut diharapkan mampu memenuhi tantangan yang diakibatkan kapitalisme global terhadap pendidikan, khususnya pendidikan Islam dalam arti seluas-luasnya.

\section{SIMPULAN}

Jika kita sepakat dengan humanisme religius sebagai paradigma, maka orientasi pendidikan Islam dari tingkat dasar sampai perguruan tinggi, formal, dan informal perlu diarahkan ke titik ini. Dengan paradigma ini, pendidikan Islam, khususnya konteks Indonesia (periferi), diharapkan mampu menyiapkan dirinya sebagai suatu sistem yang dapat diandalkan dalam menyiapkan peserta didik yang siap menghadapi segala dampak yang ditimbulkan akibat kapitalisme global yang dikuasai negara-negara Barat (center).

Dengan paradigma ini, peserta didik dapat tumbuh kembang dengan segala potensi dirinya masing-masing, dengan tetap berpegang teguh pada nilai-nilai religius. Dengan demikian pendidikan Islam tidak akan mengabaikan pentingnya pendidikan jasmani dan rohani serta pendidikan alam, tidak mendikotomikan elemen-elemen tersebut. Pada akhirnya, Insan kamil adalah sasaran pendidikan dalam Islam, dan ini dapat disasar dengan menggunakan paradigma humanisme religius.

\section{DAFTAR PUSTAKA}

Abdurrahman Mas'ud, Pengantar dalam Tobroni, Pendidikan Islam: Paradigma Teologis, Filosofis dan Spiritualitas, Malang: UMM Press, 2008

Abdurrahman Mas'ud, Menggagas Format Pendidikan Non-Dikotomik: Humanisme Religius sebagai Paradigma Pendidikan Islam, Yogyakarta: Gama Media, 2002

\footnotetext{
${ }^{44} \mathrm{Ibid}$, h. 204-205.

${ }^{4}$ Ibid, h. 206

${ }^{46} \mathrm{Ibid}$, h. 212-213.
} 
Abd. Rachman Assegaf, Filsafat Pendidikan Islam: Paradigma Baru Pendidikan Hadhari Berbasis integratif-interkonek.tif, cet. ke-1 (Jakarta: Raja Grafindo Persada, 2011

Achmadi, Ideologi Pendidikan Islam, cet. kedua, Yogyakarta: Pustaka Pelajar, 2010

Agus Sutiyono, “Sketsa Pendidikan Humanis Religius” dalam Jurnal Insania, Vol. 1, No. 2, 2009

Azyumardi Azra, Pendidikan Islam: Tradisi dan Modernisasi di Tengah Tantangan Milenium III, cet.ke-1 Jakarta: Kencana Prenada Media, 2012

M. Amin Abdullah, "Islam Dan Modernisasi Pendidikan Di Asia Tenggara : Dari Pola Pendekatan Dikotomis-Atomistik Ke Arah Integratif-Interdisiplinary",dalam bttp:/ / aminabd.wordpress.com/2010/06/20/ mempertautkan-ulum-al-diin-al-fikr-al-islamiy-dandirasat islamiyyah-sumbangan-keilmuan-islam-untuk-peradaban-global/

Nasrullah, "Telaah Kritis Dominasi dan Hegemoni Kapitalisme Global Pada Pendidikan Tinggi Indonesia" dalam http://lawunhas.wordpress.com/2014/05/02/telaah-kritis-dominasidan-hegemoni-kapitalisme-global-pada-pendidikan-tinggi-indonesial.

Sofyan Hadi, "Globalisasi dan Refermasi Evaluasi Kebijakan Pendidikan Yang Humanis dan Egaliter di Indonesia", dalam Wahidul Anam dan Syaifullah, Implementasi Pendidikan Sains di Lembaga Pendidikan Islam (Kediri, STAIN Kediri- Nadi Pustaka Press, 2010)

Tobroni, Pendidikan Islam: Paradigma Teologis, Filosofis dan Spiritualitas (Malang: UMM Press, 2008

bttp:/ / paschall-ab.blogspot.com/2013/02/ kapitalisme-global-dan-debumanisasi.btml

http:/ / amadanwar.blogspot.com/2012/12/ sistem-kapitalisme-global.btml

bttp:/ / wmw.kompas.com/kompas-cetak/0304/ 28/ nasional/280846.htm 